\title{
Effects of heavy metals on morphological characteristics of Taraxacum officinale Web growing on mine soils in NE Italy
}

\author{
Claudio Bini ${ }^{\text {a }}$, Mohammad Wahsha ${ }^{\mathrm{a}, *}$, Silvia Fontana ${ }^{\mathrm{a}}$, Laura Maleci ${ }^{\mathrm{b}}$ \\ a Department of Environmental Sciences, Informatics and Statistics, Ca' Foscari University of Venice, Italy \\ ${ }^{\mathrm{b}}$ Department of Evolutionary Biology, University of Florence, Italy
}

\section{A R T I C L E I N F O}

Article history:

Received 7 April 2012

Accepted 21 July 2012

Available online 27 July 2012

\section{Keywords:}

Heavy metals

Mine soils

Taraxacum officinale

Plant morphology

Phytoremediation

\begin{abstract}
A B S T R A C T
Plants growing on metal contaminated soils can uptake heavy metals and accumulate them in their tissues; the accumulation of potentially toxic elements can produce adverse effects on plant morphology and health. In this study, plants of Taraxacum officinale Web growing on mixed sulphides $(\mathrm{Cu}, \mathrm{Fe}, \mathrm{Pb}, \mathrm{Zn})$ mine waste in NE Italy were studied in order to assess the levels of potentially toxic heavy metals $(\mathrm{Cd}, \mathrm{Cr}, \mathrm{Cu}, \mathrm{Fe}, \mathrm{Pb}, \mathrm{Zn}$ ) in plants in relation to soil, and to investigate the accumulation ability and morphological response to environmental stress. T. officinale accumulates relatively high amounts of different metals in both shoots and roots, with positive translocation factor ( $\mathrm{TF} \geq 1$ ). Micromorphological observations on the leaf anatomy of contaminated plants revealed significant reduction in the leaf thickness, changes in intercellular spaces and in cell structural organization in comparison to plants grown on unpolluted soil. The recorded morphological changes appear to be related to contamination levels in soils.
\end{abstract}

(C) 2012 Elsevier B.V. All rights reserved.

\section{Introduction}

The restoration of metal-contaminated sites is one of the most important environmental issues. Soil pollution by chemicals poses serious hazards to surface and ground waters, plants and humans, and presents relevant social, sanitary and economic costs (only in the U.S. up to $250 \$ \mathrm{~m}^{-3}$ soil; Adriano et al., 1995; Bini, 2010). Metal accumulation in soil diminishes soil fertility, microbial activity and plant growth (Lehoczky et al., 1996). Moreover, trace elements are very persistent, can interact with plant roots by adsorption or release from the soil particles, and therefore increase the risk of long-term soil pollution and of toxic effects on organisms (Rosselli et al., 2006).

The assessment of soil contamination by metals has been extensively carried out through plant analysis (Blaylock et al., 2003; Brooks, 1998; Ernst, 1996; Wenzel et al., 1993); both wild and cultivated plant species have been frequently used as (passive accumulative) bioindicators for large scale and local soil contamination (Baker, 1981; Baker and Brooks, 1989; Bargagli, 1993; Zupan et al., 1995, 2003).

In the last decades, attention has been deserved to plants as tools to clean up metal-contaminated soils by the low cost and environmental friendly technique of phytoremediation (Adriano et al., 1995; Baker et al., 2000). This technology is focused on the ability of plants to accumulate high heavy metal concentrations (up to 100 times the normal concentration) in their aerial parts (i.e. they are

\footnotetext{
* Corresponding author at: Department of Environmental Sciences, Dorsoduro, 2137, 30123 Venice, Italy. Tel.: + 39 412348918; fax: + 39412348584.

E-mail addresses: bini@unive.it (C. Bini),wahsha@hotmail.com (M. Wahsha).
}

hyperaccumulator plants as defined by Baker, 1981). The plant ability to uptake metals was firstly applied in phytomining projects (Brooks and Robinson, 1998; Ernst, 1993; Helios-Rybicka, 1996; Mc Grath, 1998; Vergnano Gambi, 1992), and only successively, when environmental contamination became a global concern, it was recognized as an useful tool for remediation projects (Adriano et al., 1995; Bini, 2010, 2005; Bini et al., 2000b; Mc Grath, 1998; Salt et al., 1995). Indeed, tolerant or accumulator populations of higher plants may colonize naturally or even anthropogenic metal-enriched areas, accompanying the disappearance of sensitive plants. Therefore, they may be utilized in restoration of such areas. The choice of plants is a crucial aspect for the remediation techniques. Up to now, more than 400 plants that accumulate metals are reported, Brassicaceae being the family with the largest number of accumulator species (Bini, 2010; Marchiol et al., 2004; Mc Grath, 1998).

Heavy metal accumulation is known to produce significant physiological and biochemical responses in vascular plants (Mangabeira et al., 2001). As stated by Preeti and Tripathi (2011), there is a direct relationship between chemical characteristics of soil, heavy metals' concentration and morphological and biochemical responses of plants. Yet, metabolic and physiological responses of plants to heavy metal concentration can be viewed as potentially adaptive changes of the plants during stress.

Plants growing on abandoned mine sites and naturally metalenriched soils (e.g. serpentine soils) are of particular interest in this perspective, since they are genetically tolerant to high metal concentrations, as reported by several authors (Bini, 2005; Brooks, 1998; Brooks et al., 1977; Giuliani et al., 2008; Maleci et al., 1999; Pandolfini et al., 1997; Vergnano Gambi, 1992), who studied 
endemic serpentine flora (Alyssum bertoloni, A. murale, Silene paradoxa, Stachys serpentini, Thymus ophioliticus) at various sites in the world. All these authors agree that morphological, physiological and phytochemical characters of serpentine plants are strongly dependent on the substrate composition (what Jenny, in 1989, called "the serpentine syndrome"), and that they are likely metal accumulator or tolerant ecotypes.

Understanding the mechanisms of metal bioaccumulation by plants species and of metal bioreduction by microorganisms is a clue to the efficiency of phytoremediation techniques. The localization and the chemical form of metals in cells are key information for this purpose (Kidd et al., 2009; Sarret et al., 2001). After their assimilation by plants, heavy metals could interfere with metabolic processes and are potentially toxic (Lopareva-Pohu et al., 2011); phytotoxicity results in chlorosis, weak plant growth, yield depression, and may be accompanied by disorders in plant metabolism such as reduction of the meristematic zone (Maleci et al., 2001), plasmolysis and reduced chlorophyll and carotenoids production (Corradi et al., 1993). Mangabeira et al. (2001) studied the ultrastructure of different organs of tomato plants (root, stem, leaf) which showed visible symptoms of $\mathrm{Cr}$ toxicity, and argued that $\mathrm{Cr}^{\mathrm{VI}}$ induces changes in the ultrastructure of these organs. Similar findings were reported by Vasquez et al. (1991) for $\mathrm{Cd}$ in vacuoles and nuclei of bean roots. Since both these metals are known to be inessential to plant nutrition, it is suggested that they are likely confined in roots by a barrier-effect as defence strategy during stress. Conversely, essential metals such as $\mathrm{Zn}$ and $\mathrm{Cu}$ are easily translocated to the aerial parts, as reported by Fontana et al. (2010).

Among wild plants, the common dandelion (Taraxacum officinale Web) has received attention (Bini et al., 2000a; Królak, 2003; Simon et al., 1996; Zupan et al., 2003) as bioindicator plant, and has been also suggested in remediation projects (Turuga et al., 2008), given its ability to uptake and store heavy metals in the aerial tissues. T. officinale is a very common species, widely diffused in Central and Southern Europe, easy to identify and greatly adaptable to every substrate (Keane et al., 2001; Malawska and Wilkomirski, 2001). Moreover, this species is commonly collected to be used in cooking as fresh salad or boiled vegetable, and is used also in ethnobotany and traditional pharmacopoeia (Rosselli et al., 2006). Therefore, when grown on heavily contaminated soils, it may be potentially harmful if introduced in dietary food, as it occurs in many countries.

Previous studies of our research group (Bini et al., 2000a; Fontana et al., 2010) investigated the heavy metal concentration of soils developed from mine waste material, and the wild plants (Plantago major, Silene dioica, Stachys alopecuros, Stellaria nemorum, T. officinale, Vaccinium myrtillus, Gymnocarpium dryopteris, Gymnocarpium robertianum, Salix caprea, Salix eleagnos, Salix purpurea) growing on those contaminated soils, in order to determine the extent of heavy metal dispersion, and the uptake by both known and unreported metal-tolerant plant species. The results showed that $T$. officinale is a species tolerant to high metal concentrations, and suggested to use it as a bioindicator plant. Metals accumulated preferentially in roots, but also leaves proved accumulator organs, being able to store up to $200 \mathrm{mg} \mathrm{kg}^{-1} \mathrm{~Pb}$ and $160 \mathrm{mg} \mathrm{kg}^{-1} \mathrm{Zn}$, showing only little damages (e.g. reduced foliar surface, reduced plant development).

In this work we report the results of a study carried out on wild T. officinale growing on soils of abandoned mine sites in NE Italy, with the following objectives:

- to determine heavy metal concentration in T. officinale leaves and roots;

- to calculate the Bioaccumulation Factor (BCF) and the Transfer Coefficient (TF) from soil to plant (roots and shoots); and

- to highlight possible damages at anatomical and cytological level on the aerial part of the plant.

\section{Materials and methods}

\subsection{Site description}

The Imperina Valley mining area is located in the mountain district of Belluno (NE Italy), with an altitude ranging between $543 \mathrm{~m}$ and $990 \mathrm{~m}$ above sea level. The geological substrate consists of rocks of the metamorphic basement (Pre-Permian), in tectonic contact with dolomite rocks (Dolomia Principale, Upper Triassic). The exploitation area is located along the tectonic contact; it consists of a deposit of mixed sulphides (Fe, $\mathrm{Cu}-\mathrm{Pb}-\mathrm{Zn}$ ), composed primarily of cupriferous pyrite, pyrite and chalcopyrite, with minor amounts of other metallic minerals. Waste dump materials are dispersed over a large area in the territory, and contain relatively high amounts of toxic metals, with these average values: $\mathrm{Cu}=1.3 \%, \mathrm{~Pb}=0.2 \%, \mathrm{Zn}=1 \%, \mathrm{Cd}=8 \mathrm{mg} \mathrm{kg}^{-1}$, $\mathrm{Cr}=75 \mathrm{mg} \mathrm{kg}^{-1}$, and $\mathrm{Ni}=62 \mathrm{mg} \mathrm{kg}^{-1}$ (Campana et al., 2007). The recorded metal amounts confirm the waste composition to be determined by weathering products of primary minerals (cupriferous pyrite, sphalerite, galena), where $\mathrm{Cr}$ and $\mathrm{Ni}$ are present in traces. Full information on the geological and environmental setting is available in Fontana et al. (2010) and references therein.

Mining activity in the investigated areas dates back at least to the Middle Age and flourished in the 19th and 20th centuries, until final closure in 1962.

Copper and sulphur were the main products extracted. Since the beginning of the 15th century, and until the final closure, copper was extracted and processed directly in situ through roasting, a method with a severe impact on the area due to acid rain formation and intensive wood cutting, that left bare soils. Afterwards, in the last century, vegetation cover was naturally re-established, pedogenetic processes started again, and a new soil type, a Spolic Technosol (WRB, 2006), began to form.

The vegetation cover varies strongly at different sites, depending on landscape morphology and elevation, climate and microclimate, age of mine waste and soil evolution. It is mainly constituted of mixed woods (Abies alba, Picea abies, Fagus sylvatica, Quercus spp., Fraxinus ornus and Ostrya carpinifolia), with clearances where herbaceous and shrubby vegetation (the most abundant is willow) prevail over the arboreal one. Some of herbaceous species, as plantain (P. major), dandelion (T. officinale), moon plant (S. dioica) and fescue (Festuca inops) are pioneer and very resistant plants which colonize highly degraded areas, especially at sites where mine activity ceased a few decades ago, and soil is highly infertile and phytotoxic.

\subsection{Field sampling and laboratory analyses}

Preliminary investigations carried out in 2008/2009 in the mined area and the conterminous zone allowed identification of sites with different geo-morpho-pedological conditions, vegetation coverage and anthropogenic impact. Three contaminated areas, each with two sites (1-2, riverbed upstream; 3-4, roasting area; 5-6, permanent meadow downstream) and a not-contaminated site over dolomite (background control), were selected (Fig. 1) and sampled according to the procedures described by Hood and Jones (1997) and Margesin and Schinner (2005).

In the period between spring-summer 2010, soil pits were opened and described following Italian national guidelines (Fontana et al., 2010). All locations were sampled for topsoil $(0-30 \mathrm{~cm})$ and wild dandelion plants. Afterwards, samples of both soils and plants were recovered to the laboratory for routine and geochemical analyses. Full information on field sampling and laboratory methods is available in Wahsha et al. (2012).

\subsubsection{Plant sampling}

At four of the previously selected sites (sites 2, 4, 6, and control), during spring 2011, T. officinale specimens have been collected 


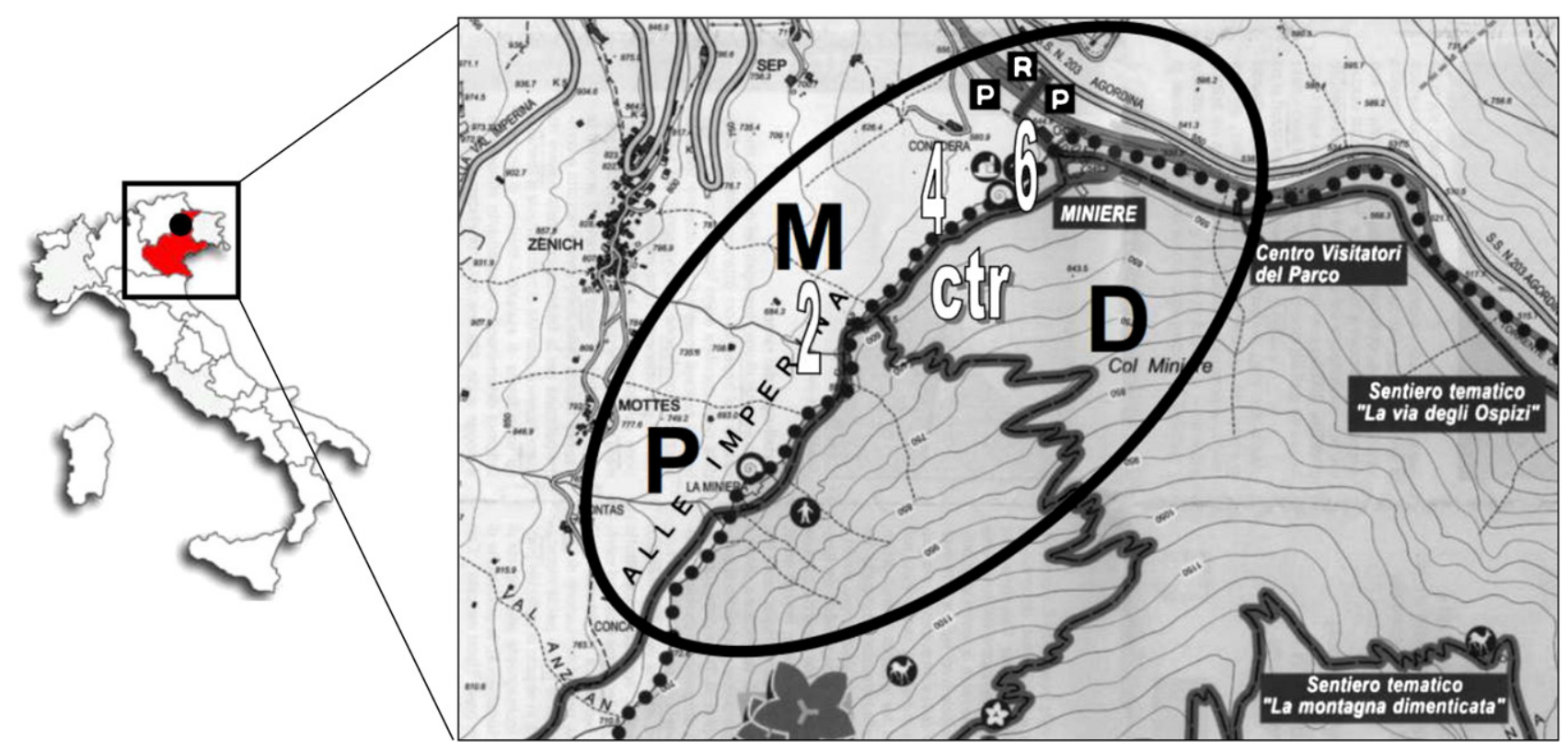

Fig. 1. Location of the studied area and sampling sites $(2,4,6$, ctr $)$ of Imperina Valley. ctr $=$ control, $M=$ metamorphic basement, $P=$ phyllite, $D=$ dolomite.

according to Jones (2001). At least five specimens of dandelion plants (at the early vegetative phase and normal morphological appearance) were sampled at each site with their corresponding soil clod. Successively, plants with their natural substrate were cultivated in pots at the Botanical Garden of the University of Florence, under the supervision of the authors, until exhausted life cycle, during winter. Foliar parameters were carefully measured in order to control regular growth.

During the vegetative period, small pieces of leaves of dandelion, taken in the middle part of the leaf length (three replicates for each sample) were pre-fixed in $2.5 \%$ glutaraldehyde in $0.1 \mathrm{M}$ phosphate buffer at a $\mathrm{pH} 6.8$, post-fixed in $2 \% \mathrm{OsO}_{4}$ in the same buffer, then dehydrated and embedded in Spurr's epoxy resin. Semi-thin sections were stained with toluidine blue and observed with a Leitz L. M. for a general overview of the leaf morphology. Ultrathin sections were stained with uranyl-acetate and subsequently with lead citrate to observe leaf ultrastructure. The observations were performed with a Philips EM 300 transmission electron microscope.

\subsubsection{Metal accumulation efficiency}

To evaluate the metal accumulation efficiency in plants, we have calculated the bioaccumulation coefficient factor (BCF) and translocation factor (TF). BCF is defined as the ratio of metal concentration in the roots to that in soil, and TF is the ratio of metal concentration in shoots to the roots (Malik et al., 2010). Both BCF and TF have to be considered while evaluating whether a particular plant is a metal hyperaccumulator. Therefore, plants with both $\mathrm{BCF}$ and $\mathrm{TF}$ greater than one $(\mathrm{BCF}>1, \mathrm{TF}>1)$ have the potential to be used in phytoextraction. Besides, plants with bioaccumulation factor greater than one and translocation factor less than one ( $\mathrm{BCF}>1$ and $\mathrm{TF}<1$ ) have the potential for phytostabilization. A hyperaccumulator plant should have $\mathrm{BCF}>1$ or $\mathrm{TF}>1$, as well as total accumulation $>1000 \mathrm{mg} \mathrm{kg}^{-1}$ of $\mathrm{Cu}, \mathrm{Co}, \mathrm{Cr}$ or $\mathrm{Pb}$, or $>10000 \mathrm{mg} \mathrm{kg}^{-1}$ of Fe, Mn or Zn (Kabata-Pendias, 2011).

\subsection{Data analysis}

Statistical analysis of metal content in soils and plants was based on ANOVA and is presented as means \pm S.D. The statistical significance was declared when $\mathrm{p}$ value was equal to or less than 0.05 .
Statistical analyses were performed using Sigma Stat statistical software version 3.5

\section{Results}

\subsection{Heavy metals' accumulation in soils}

Waste soils are shallow, sandy loam in texture and typically unsaturated with respect to water; they have low cation exchange capacity and relatively high hydraulic conductivity that favours oxidation and alteration processes. Most $\mathrm{pH}$ values are acidic (range 4.5-7.8 depending on the lithology of parent material), which favours metal mobility. Organic carbon content is highly variable (4.0-41.0 $\mathrm{g} \mathrm{kg}^{-1}$ ), with the lowest values at the most contaminated sites. Full description of soil data is reported in Fontana et al. (2010).

Table 1 summarizes the results of the average concentrations of $\mathrm{Cd}, \mathrm{Cr}, \mathrm{Cu}, \mathrm{Pb}, \mathrm{Zn}$, and $\mathrm{Fe}$ in the soils examined. All the studied sites, out of the not-contaminated one, are strongly enriched in metals. The total concentrations of most of the investigated metals $(\mathrm{Cd}, \mathrm{Cu}$, $\mathrm{Pb}, \mathrm{Zn}$ and $\mathrm{Fe}$ ) in the soil samples were significantly higher (ANOVA $\mathrm{p}<0.05$ ) than those of the not-contaminated site, and almost all above the toxicity threshold according to the Italian legislation (D.L. $152 / 2006)$. Chromium concentration, instead, is below the legislation limits, and considerably higher in not-contaminated soil than at contaminated sites. Site 4 is the most contaminated, presenting very high metal concentrations ( $\mathrm{Cd}$ up to $4.35 \mathrm{mg} \mathrm{kg}^{-1}, \mathrm{Cu}$ up to $4100 \mathrm{mg} \mathrm{kg}^{-1}, \mathrm{~Pb}$ up to $14150 \mathrm{mg} \mathrm{kg}^{-1}$, $\mathrm{Zn}$ up to $2700 \mathrm{mg} \mathrm{kg}^{-1}$ ), with $\mathrm{Fe}$ up to $58 \%$ in the roasting area. Sites 2 and 6 too are highly contaminated by $\mathrm{Cu}, \mathrm{Pb}, \mathrm{Zn}$, and $\mathrm{Fe}$, while $\mathrm{Cd}$ concentration is slightly above the not-contaminated site, and $\mathrm{Cr}$ is well below the control value and under the detection limit at site 6

As shown in Table 2, the positive linear correlation between $\mathrm{Pb}, \mathrm{Cu}$, $\mathrm{Zn}$ and $\mathrm{Fe}(\mathrm{Cu} / \mathrm{Pb} 0.867 ; \mathrm{Pb} / \mathrm{Zn} 0.616 ; \mathrm{Cu} / \mathrm{Zn} 0.688 ; \mathrm{Cu} / \mathrm{Fe} 0.933$, and significant at $\mathrm{p}<0.05$ ) is consistent with their calcophilous behaviour, since these metals tend to form compounds with sulphur, as chalcopyrite $\left(\mathrm{CuFeS}_{2}\right)$, sphalerite $(\mathrm{ZnS})$ and galena ( $\left.\mathrm{PbS}\right)$, commonly found in the Imperina Valley ore deposits (Frizzo and Ferrara, 1994). Chromium is negatively correlated with $\mathrm{Cu}(-0.847), \mathrm{Pb}(-0.816), \mathrm{Zn}(-0.604)$ and $\mathrm{Fe}(-.0754)$. Iron presents a significant positive correlation with $\mathrm{Pb}(\mathrm{Fe} / \mathrm{Pb} 0,734)$. Furthermore, Fe is not significantly correlated with 
Table 1

Heavy metals' concentration in soils of Imperina Valley. Cd, Cr, Cu, Pb, $\mathrm{Zn}$, and Fe are expressed as mg $\mathrm{kg}^{-1}$. All the values are mean of five replicates \pm S.D.

\begin{tabular}{|c|c|c|c|c|c|c|}
\hline Sampling site & $\mathrm{Cd}$ & $\mathrm{Cr}$ & $\mathrm{Cu}$ & $\mathrm{Pb}$ & $\mathrm{Zn}$ & $\mathrm{Fe}$ \\
\hline 2 & $0.85 \pm 0.5 \mathrm{i}$ & $14 \pm 3 \mathrm{i}$ & $2822 \pm 40 \mathrm{i}$ & $11,280 \pm 37 \mathrm{i}$ & $1096 \pm 11 \mathrm{i}$ & $320,437 \pm 178 \mathrm{i}$ \\
\hline 4 & $4.35 \pm 1.1 \mathrm{i}$ & $31 \pm 2 \mathrm{i}$ & $4098 \pm 36 \mathrm{i}$ & $14,147 \pm 95 \mathrm{i}$ & $2717 \pm 13 \mathrm{i}$ & $578,632 \pm 229 \mathrm{i}$ \\
\hline 6 & $0.98 \pm 0.6 \mathrm{i}$ & $<\mathrm{DL}^{\mathrm{d}}$ & $1894 \pm 35 \mathrm{i}$ & $12,124 \pm 56 \mathrm{i}$ & $2513 \pm 20 \mathrm{i}$ & $47,571 \pm 287 \mathrm{i}$ \\
\hline Control & $0.32 \pm 0.2$ & $141 \pm 4$ & $105 \pm 6$ & $39 \pm 2$ & $95 \pm 7$ & $37,984 \pm 328$ \\
\hline It. $A v^{1, a}$ & 0.53 & 100 & 51 & 21 & 89 & 37,000 \\
\hline Int. $A v^{2, a}$ & 0.30 & 200 & 20 & 10 & 50 & - \\
\hline E. $V^{3, a}$ & 5 & 100 & 100 & 100 & 250 & - \\
\hline R.L $\mathrm{L}^{4, \mathrm{~b}}$ & - & 150 & 120 & 200 & 150 & - \\
\hline C.S.T.C ${ }^{5, ~ c ~}$ & $3-8$ & $75-100$ & $60-125$ & $100-400$ & $70-400$ & $1000^{*}$ \\
\hline
\end{tabular}

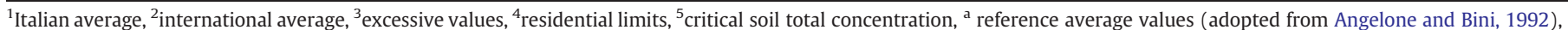

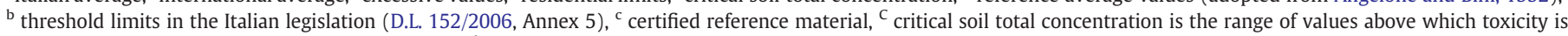
considered to be possible (source: Alloway, 1995), ${ }^{\mathrm{d}}$ less than the detection limit. * Source: Kabata-Pendias, 2011.

The letter symbol following \pm S.D within the same column indicates if there is a significant difference or not when compared to control site.

$\mathrm{i}$ indicates significant difference at $\mathrm{p}<0.05$ according to ANOVA.

$\mathrm{Cd}$, as expected considering the counteracting geochemical behaviour of the two elements.

\subsection{Heavy metals' accumulation in T. officinale plants}

The concentrations of heavy metals in roots and leaves of dandelion plants collected in Imperina Valley are presented in Table 3. Data show that at contaminated sites this plant is able to accumulate metals, except $\mathrm{Cd}$, in shoots at much higher concentrations than at the unpolluted site, and above the toxicity threshold indicated by Kabata-Pendias and Pendias (2001); the greatest amount was found at the most contaminated site (sample 4).

Cadmium concentrations in both shoots and roots of plants from sites 2, 4, and 6, are below the control value (up to $1.46 \mathrm{mg} \mathrm{kg}^{-1}$ ), and below the phytotoxicity threshold reported by Alloway (1995) for dandelion, with site 2 presenting the highest value $\left(1.05 \mathrm{mg} \mathrm{kg}^{-1}\right)$. Chromium concentrations in plants from contaminated sites are slightly higher than the detection limit $\left(1.00 \mathrm{mg} \mathrm{kg}^{-1}\right)$, and very low in comparison to the phytotoxicity threshold reported by Kabata-Pendias and Pendias (2001), consistently with concentration levels recorded in soil (see Table 1 ).

Copper and $\mathrm{Pb}$ concentrations in shoots present much higher levels ( $\mathrm{Cu}$ up to $64 \mathrm{mg} \mathrm{kg}^{-1}$; $\mathrm{Pb}$ up to $193 \mathrm{mg} \mathrm{kg}^{-1}$ ) than at the notcontaminated site. However, $\mathrm{Cu}$ is nearly equally accumulated in shoots and roots, while $\mathrm{Pb}$ is slightly more abundant in shoots than in roots. Zinc levels in T. officinale shoots from sites 2 and 6 fall within the normal range (27-150 $\mathrm{mg} \mathrm{kg}^{-1}$ ) given by Kabata-Pendias and Pendias (2001), while plants from site 4 present $\mathrm{Zn}$ concentrations slightly above the normal values $\left(189 \mathrm{mg} \mathrm{kg}^{-1}\right)$. Iron concentrations in leaves show a wide range of variation, with the highest level up to $890 \mathrm{mg} \mathrm{kg}^{-1}$ at site 4 . However, this metal is not considered toxic unless at very high concentration: above $1000 \mathrm{mg} \mathrm{kg}^{-1}$ according to Kabata-Pendias (2011).

Heavy metals in roots of $T$. officinale present lower concentrations with respect to leaves, with the exception of $\mathrm{Cu}$ at site 4 . This suggests the ability of this plant to translocate most metals from roots to shoots. This is particularly evident for Fe and $\mathrm{Zn}$ (2-3 fold), which are essential micronutrients, while $\mathrm{Pb}$ and especially $\mathrm{Cu}$ are less prone ( 0.20 and 0.0 fold, respectively) to translocate from roots.

\section{Table 2}

Linear correlation coefficients calculated on metal concentrations in soils. Indicated correlation is significant at the 0.05 level (bold: 2 -tailed).

\begin{tabular}{lllllll}
\hline & $\mathrm{Cd}$ & $\mathrm{Cr}$ & $\mathrm{Cu}$ & $\mathrm{Pb}$ & $\mathrm{Zn}$ & $\mathrm{Fe}$ \\
\hline $\mathrm{Cd}$ & 1 & & & & & \\
$\mathrm{Cr}$ & 0.201 & 1 & & & & \\
$\mathrm{Cu}$ & -0.209 & $\mathbf{- 0 . 8 4 7}$ & 1 & & & \\
$\mathrm{~Pb}$ & -0.515 & $\mathbf{- 0 . 8 1 6}$ & $\mathbf{0 . 8 6 7}$ & 1 & & \\
$\mathrm{Zn}$ & -0.248 & $\mathbf{- 0 . 6 0 4}$ & $\mathbf{0 . 6 8 8}$ & $\mathbf{0 . 6 1 6}$ & 1 & \\
$\mathrm{Fe}$ & -0.003 & $\mathbf{- 0 . 7 5 4}$ & $\mathbf{0 . 9 3 3}$ & $\mathbf{0 . 7 3 4}$ & 0.440 & 1 \\
\hline
\end{tabular}

The calculation of metal accumulation efficiency shows that most of the examined samples have BCF much less than $1(<0.01)$ and TF more than 1 (up to 3.3 for Fe and 2.7 for $\mathrm{Zn}$ ), although the concentration of heavy metals remained below $1000 \mathrm{mg} \mathrm{kg}^{-1}$ (Table 4). The calculation of translocation factors highlights that dandelion translocates and accumulates metals in the aerial parts, in particular Fe $\left(\mathrm{TF}_{\mathrm{Fe}}=2.55-3.98\right)$ and $\mathrm{Zn}\left(\mathrm{TF}_{\mathrm{Zn}}=1.51-2.67\right)$.

\subsection{Plant morphology}

The leaf morphology of dandelion plants grown on heavy-metal contaminated substrate of sites 2,4 , and 6 , in comparison to plants grown on not-contaminated substrate, was examined to ascertain possible toxic signals.

Light microscopy observations carried out on the leaf lamina (Fig. 2) show a clear difference in the foliar organization of notcontaminated and contaminated samples. The unpolluted samples present a well organized palisade and spongy photosynthetic parenchyma (Fig. 2a). Samples from the less contaminated substrate (site 2) present a leaf structure (Fig. 2b) similar to the control (Fig. 2a), but palisade parenchyma appears less organized, and a small reduction of leaf thickness is visible. Plant samples from site 4 (the most contaminated), instead, present a leaf parenchyma constituted of few roundish cells with large intercellular spaces, palisade structure lacking completely, and strong reduction of leaf thickness in comparison to samples from not-contaminated site (Fig. 2d). Samples from site 6 , grown on medium-contaminated soil, present a morphology with intermediate characters in comparison to samples from sites 2 and 4, i.e. lack of an actually organised palisade parenchyma, and a reduced foliar thickness (Fig. 2c).

Comparing the leaf morphology with their metal content (see Table 3), it appears that the poor structural organisation, and the reduced foliar thickness of the contaminated plants, are strictly related to soil contamination. Observation of the modified morphological characteristics of the plant and their heavy metal content suggests that plants with high concentration of heavy metals usually show growth abnormalities.

Preliminary ultrastructure observations of the parenchyma cells of contaminated samples show mitochondrial structure alteration, with lacking or reduced internal membranes at increasing metal content, as it is evident in sample 4 (Fig. 3a), in comparison to the notcontaminated sample (Fig. 3b). Instead, chloroplast organization does not present significant differences, particularly in number and compartmentalization of thylacoids.

\section{Discussion}

Our results show that the heavy metal concentrations in T. officinale are affected by their concentration in the soil; therefore, $T$. officinale qualifies as a bioindicator. A positive trend between metal concentration 
Table 3

Concentration of heavy metals in Taraxacum ( $\mathrm{mg} \mathrm{kg}^{-1}$ dry weight). All the values are mean of five replicates \pm S.D. ( ${ }^{\mathrm{a}}$ below detection limit).

\begin{tabular}{|c|c|c|c|c|c|c|c|c|c|c|c|c|}
\hline \multirow[t]{2}{*}{ Sampling site } & \multicolumn{2}{|l|}{$\mathrm{Cd}$} & \multicolumn{2}{|l|}{$\mathrm{Cr}$} & \multicolumn{2}{|l|}{$\mathrm{Cu}$} & \multicolumn{2}{|l|}{$\mathrm{Pb}$} & \multicolumn{2}{|l|}{$\mathrm{Zn}$} & \multicolumn{2}{|l|}{$\mathrm{Fe}$} \\
\hline & Leaves & Roots & Leaves & Roots & Leaves & Roots & Leaves & Roots & Leaves & Roots & Leaves & Roots \\
\hline 2 & $1.00 \pm 0.1$ & $1.05 \pm 0.1$ & $3.22 \pm 0.7$ & $1.00 \pm 0.0$ & $64 \pm 4$ & $58 \pm 4$ & $120 \pm 8$ & $99.8 \pm 1$ & $101 \pm 28$ & $67 \pm 8$ & $620 \pm 4$ & $187 \pm 22$ \\
\hline 4 & $0.29 \pm 0.1$ & $0.17 \pm 0.1$ & $3.67 \pm 0.4$ & $1.71 \pm 0.2$ & $49 \pm 3$ & $50 \pm 2$ & $193 \pm 7$ & $142 \pm 7$ & $189 \pm 17$ & $71 \pm 6$ & $890 \pm 14$ & $320 \pm 24$ \\
\hline 6 & $0.69 \pm 0.2$ & $0.34 \pm 0.3$ & $2.58 \pm 0.1$ & $0.95 \pm 0.3$ & $45 \pm 2$ & $40 \pm 4$ & $147 \pm 2$ & $118 \pm 2$ & $115 \pm 8$ & $59 \pm 2$ & $490 \pm 19$ & $167 \pm 14$ \\
\hline Control & $1.46 \pm 0.3$ & $1.33 \pm 0.4$ & $<\mathrm{DL}^{\mathrm{a}}$ & $<\mathrm{DL}^{\mathrm{a}}$ & $9 \pm 1$ & $7 \pm 1$ & $3.32 \pm 1$ & $1.41 \pm 2$ & $44 \pm 9$ & $33 \pm 4$ & $470 \pm 24$ & $108 \pm 27$ \\
\hline
\end{tabular}

in soils and plants at different sites (not-contaminated, slightly polluted, moderately polluted, strongly polluted) was detected. T. officinale accumulated metals $(\mathrm{Cd}, \mathrm{Cr}, \mathrm{Fe}, \mathrm{Pb}, \mathrm{Zn})$ in leaves more than in roots. In agreement with our results, Simon et al. (1996), Malawska and Wilkomirski (2001), Keane et al. (2001), Zupan et al. (2003) and Savinov et al. (2007) showed that the concentrations of heavy metals in T. officinale specimens depended on their concentrations in the soil, although there were different patterns for the metals analysed $(\mathrm{Cd}, \mathrm{Cu}, \mathrm{Zn})$. Conversely, other studies carried out with $T$. officinale both in the field and in pot, indicated that $\mathrm{Cr}$ concentrations were higher in roots than in leaves (Bini et al., 2008; Mangabeira et al., 2001). So, the accumulation ability of T. officinale seems to depend more on soil characteristics (e.g. pH, organic carbon content, texture) than on metal concentration in soil. Results on metal translocation ability for $\mathrm{Pb}$ and $\mathrm{Cd}$ show that these metals are translocated from roots to shoots, having translocation factors slightly higher than $1\left(\mathrm{TF}_{\mathrm{Pb}}=1.10-1.52 ; \mathrm{TF}_{\mathrm{Cd}}=0.95-2.56\right)$ in almost all the investigated plants. This is not consistent with results presented in recent literature, since $\mathrm{Pb}$, as well as $\mathrm{Cd}$, are generally thought (Kabata-Pendias and Mukherjee, 2007; Vandecasteele et al., 2002) to be blocked as not-essential elements in roots, thereby suggesting some exclusion strategy by plants. It is interesting to note that plants collected at the unpolluted site present $\mathrm{Cd}$ concentrations in both leaves and roots higher than at the contaminated sites: the control parent material is dolomite, and this could represent a source of Ca-substituted Cd, as reported by Dubois et al. (1998) in soils from Switzerland.

The metal translocation ability, combined with rapid growth, qualifies dandelion as good candidate for phytoremediation of polluted soils. The examined plants were capable to uptake and translocate more than one metal from roots to shoots. Based on the highest TF values (see Table 4), T. officinale can be used for phytoextraction of $\mathrm{Zn}$ and Fe.

Since $T$. officinale is used in traditional pharmacopoeia against chronic liver diseases, as diuretic and appetite stimulating, and also in cooking, both as fresh salad and as boiled vegetable, metals absorbed may accumulate in edible parts at a higher concentration than what is legally admitted in nutritional products, and enter the food chain, constituting a possible hazard for humans. Rosselli et al. (2006), however, did not find any correlation between metals in soil and in T. officinale roots, and support the hypothesis of a regulation mechanism which adjusts the metal concentrations in the leaves to a given level, e.g. by storage in the root tissues. This concentration level (i.e. metal saturation) corresponds to the amount that is naturally absorbed by the plant for nutritional purposes, since $\mathrm{Cu}$ and $\mathrm{Zn}$ are essential trace elements, and this does not allow to determine a metal-concentration limit in soils above which the consumption of T. officinale could be prohibited. Concerning $\mathrm{Zn}$, its accumulation in plant tissues increases with metal concentration in the substrate, but does not attain the saturation level, (i.e. T. officinale is an indicator plant for Zn), consistently with statements by Argese et al. (2001), who studied micronutrient uptake in different edible plants.

A clear relation exists between heavy metal content in soil and plants, and morphological alteration (reduced leaf thickness, cellular organization), including plant development and biomass weight decrease, as reported also in studies on Avena sativa, Hordeum vulgare (Argese et al., 2001), Brassica campestris and Apium graveolens (Yang et al., 2011; Zong et al., 2007). Plant uptake of heavy metals from soil occurs either passively with the mass flow of water into the roots, or through active transport crossing the plasma membrane of root endodermal cells (Kabata-Pendias, 2004; Mun et al., 2008). In the presence of heavy metals, plants may present phytotoxicity symptoms, manifested through chlorosis, leaf necrosis, reduced development of the whole plant (roots, stem, leaves), as observed by Maleci et al. (2001) in Calendula arvensis. At cellular level, Mangabeira et al. (2001) noted marked changes in chloroplast organization, fewer thylacoids and degeneration of the cellular membranes in $\mathrm{Cr}$-contaminated tomato (Solanum lycopersicum) plants. Preeti and Tripathi (2011) found that in Albizia procera there is a direct relationship between the concentration of toxic metals $(\mathrm{As}, \mathrm{Cd}, \mathrm{Pb})$ and morphological and biochemical responses of plants, and interpreted these responses as potentially adaptive changes which favour the functioning of the plants during or after stress.

Morphological and biochemical responses are probably due to high metal concentrations that damaged plant roots, and inhibited uptake of nutrients, thus inhibiting normal plant growth. Studies carried out on the toxic effects of $\mathrm{Cr}$ in different plants (marigold, sage, dandelion, maize, tomato) showed reduction in root size, damaged root cap and epidermal cells, collapsed trichomes and root hairs (Corradi et al., 1993, 1991; Maleci, et al., 2001; Mangabeira et al., 2001).

In wild specimens of marigold (C. arvensis, $C$. officinalis) treated with different $\mathrm{Cr}(\mathrm{III})$ concentrations, Maleci et al. (2001) found a reduction of the meristematic zone of the root tip, and early tissue differentiation, and therefore a reduced elongation of the roots.

Table 4

Heavy metals translocation (TF) and biological concentration (BCF) factors of $T$. officinale.

\begin{tabular}{|c|c|c|c|c|c|c|c|c|c|c|c|c|}
\hline \multirow[t]{2}{*}{ Site } & \multicolumn{2}{|l|}{$\mathrm{Cd}$} & \multicolumn{2}{|l|}{$\mathrm{Cr}$} & \multicolumn{2}{|l|}{$\mathrm{Cu}$} & \multicolumn{2}{|l|}{$\mathrm{Pb}$} & \multicolumn{2}{|l|}{$\mathrm{Zn}$} & \multicolumn{2}{|l|}{$\mathrm{Fe}$} \\
\hline & $\mathrm{TF}$ & ${ }^{\mathrm{a}} \mathrm{BCA}$ & $\mathrm{TF}$ & ${ }^{\mathrm{b}} \mathrm{BCA}$ & TF & ${ }^{\mathrm{b}} \mathrm{BCA}$ & $\mathrm{TF}$ & ${ }^{\mathrm{b}} \mathrm{BCA}$ & TF & ${ }^{\mathrm{b}} \mathrm{BCA}$ & $\mathrm{TF}$ & ${ }^{\mathrm{c} B C A}$ \\
\hline 1 & 2.11 & 3.79 & 1.84 & 11.90 & 1.34 & 1.90 & 1.52 & 0.59 & 2.10 & 7.70 & 2.55 & 4.07 \\
\hline 2 & 0.95 & 12.36 & 3.22 & 3.22 & 1.11 & 2.05 & 1.20 & 0.71 & 1.51 & 6.11 & 3.32 & 5.84 \\
\hline 3 & $\mathrm{NC}$ & $\mathrm{NC}$ & 5.01 & 0.76 & 1.05 & 16.01 & 1.30 & 32.14 & 1.73 & 14.90 & 3.30 & 73.99 \\
\hline 4 & 2.01 & 0.78 & 2.72 & 6.79 & 1.13 & 0.98 & 1.25 & 0.97 & 1.95 & 2.35 & 2.95 & 2.89 \\
\hline 5 & 2.56 & 0.91 & 5.12 & 1.27 & 1.20 & 12.41 & 1.10 & 22.30 & 1.80 & 13.45 & 3.98 & 36.95 \\
\hline 6 & 1.71 & 1.74 & 2.15 & $\mathrm{NC}$ & 0.98 & 2.64 & 1.40 & 1.26 & 2.67 & 2.61 & 2.79 & 67.27 \\
\hline Control & 1.01 & 41.60 & NC & NC & 1.30 & 3.70 & 2.40 & 3.62 & 1.33 & 34.74 & 4.35 & 28.43 \\
\hline
\end{tabular}

\footnotetext{
a $\mathrm{n}\left(10^{-1}\right)$.

b $\mathrm{n}\left(10^{-2}\right)$

c $\mathrm{n}\left(10^{-4}\right)$.
} 

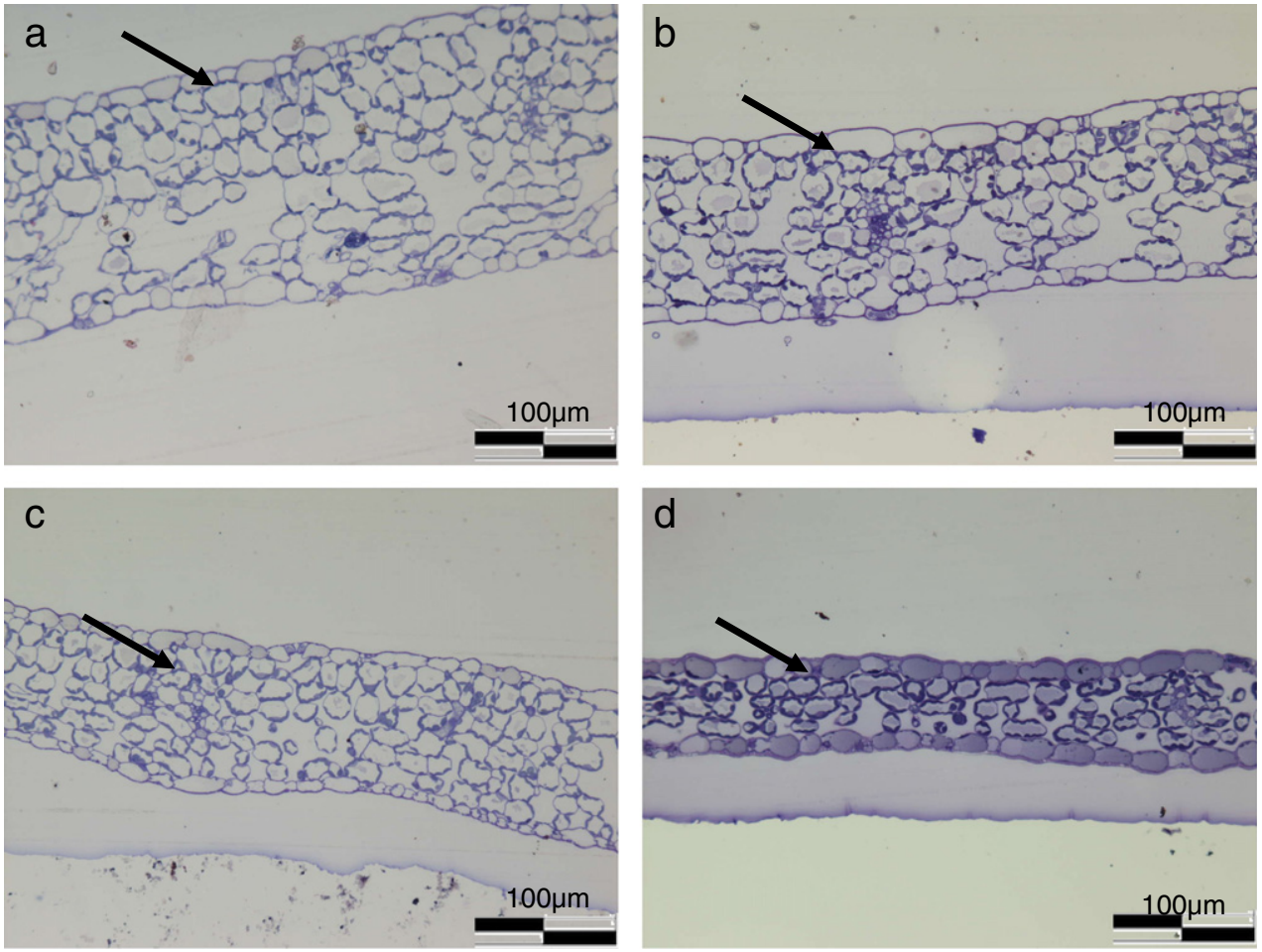

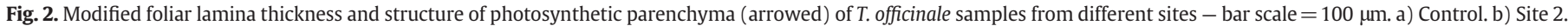
c) Site 6. d) Site 4

In wild sage (Salvia sclarea L.) treated with $\mathrm{Cr}(\mathrm{VI})$ concentrations, Corradi et al. (1993) noted that, although seed germination was not affected, when the emergent radicle came in contact with the $\mathrm{Cr}$ solution, its growth was inhibited, although early shoots and cotyledons developed normally. Moreover, chlorosis and depressed carotenoid content were observed.

In dandelion (T. officinale) cultivated in pot and amended with compost, and in wild dandelion specimens grown on metal-contaminated soil, Bini et al. (2000b, 2008) found that metal uptake and translocation to the aerial parts were reduced, except for $\mathrm{Zn}$, which has an antagonist effect with other metals. This is particularly evident with $\mathrm{Cr}$, which accumulates in roots, that act as a barrier against $\mathrm{Cr}$ translocation (Bini et al., 2008). However, no toxic symptoms were observed in both experiments, suggesting dandelion to be a Cr-tolerant/excluder plant which could be used in phytostabilization projects.

Also plants growing on naturally contaminated soils (e.g. A. bertoloni, A. murale, Thymus striatus ssp. ophioliticus on serpentine soils) present particular characteristics in comparison to plants of the same species, growing on not-contaminated soils (Maleci et al., 1999): reduced internodes, highly lignified stem, and abundant anthocyanins. These plants
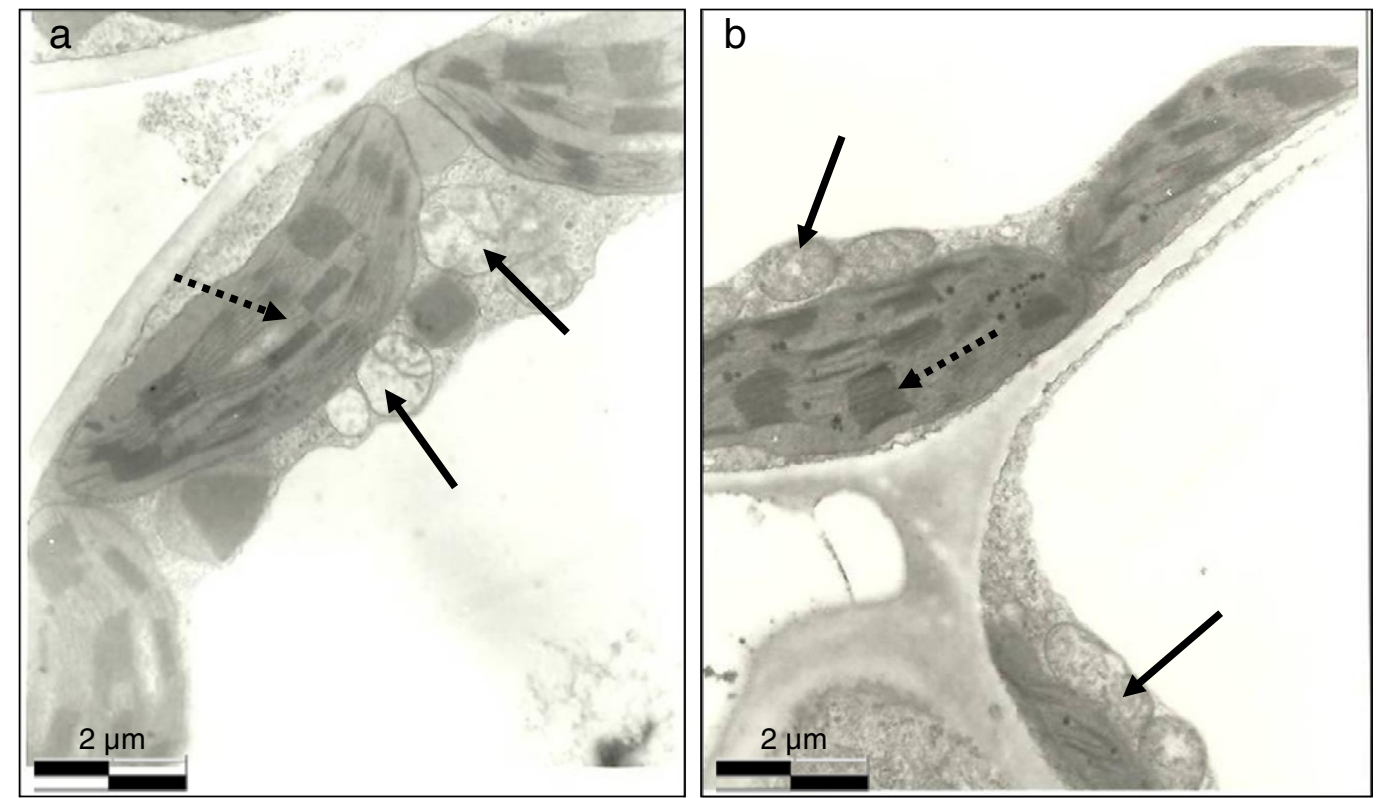

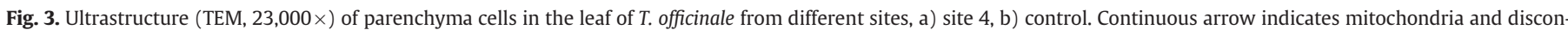
tinuous arrow indicates thylakoids. 
are likely affected by the "serpentine syndrome" (Jenny, 1989): low $\mathrm{Ca}-\mathrm{Mg}$ ratio, and high amounts of $\mathrm{Cr}, \mathrm{Cu}$, and Ni. However, they do not present particularly toxic effects, being adapted to these particular ecological conditions (i.e. they are genetically tolerant to high amounts of heavy metals), and therefore of interest to phytoremediation. It is noteworthy to point out, however, that the ability of plants to accumulate heavy metals in different parts is somewhat independent of the species; rather, it depends on local factors as soil and pedoclimate (particularly temperature, aeration and water content) and on plant physiology and ageing (Baker and Brooks, 1989; Mikulka et al., 2009). Moreover, a counteracting behaviour of essential and toxic elements is likely to occur owing to a barrier effect of the roots, as reported by Bini et al. (2008).

\section{Conclusions}

Soil analysis of the studied area showed low pH, low cation exchange capacity, percentage of sand higher than $50 \%$, absence of structure and low capacity of the soil to retain water and metals. High heavy metal $(\mathrm{Cd}, \mathrm{Cr}, \mathrm{Cu}, \mathrm{Pb}, \mathrm{Zn}, \mathrm{Fe})$ concentrations were recorded in both soils and selected plants ( $T$. officinale) growing on mine tailings. There is a relationship between metal content in soils and plants, which qualifies T. officinale as an indicator plant, rather than accumulator.

The ability of $T$. officinale to uptake and translocate heavy metals, particularly the essential micronutrients $\mathrm{Zn}$ and $\mathrm{Fe}$, from soil to plant was ascertained.

Plants proved to accumulate heavy metals in their shoots more than in roots. This is an effective and cheap option for phytoremediation of contaminated areas and also to decrease erosion risk.

The accumulation of metals in plants, however, affects the normal processes of plant metabolism. The study shows that there is a relationship between high metal contents in plants and their modified morphology: strong reduction of leaf thickness, modified parenchyma structure, and decreased mitochondria organization were ascertained, although toxic symptoms were apparently absent.

In conclusion, the evaluation of metal uptake by plants, combined with geobotanical observations, proved a useful tool to find tolerant plant populations to be used in revegetation programs aimed at reducing the environmental impact of contaminated areas. The selection of new genotypes from metal-tolerant species will bring large advances in phytoremediation of contaminated sites. Further investigations may help understanding if dandelion could be a metal-tolerant plant to grow on slightly metal-contaminated soils for restoration purposes.

\section{References}

Adriano, D.C., Chlopecka, A., Kapland, D.I., Clijsters, H., Vangrosvelt, J., 1995. Soil contamination and remediation philosophy, science and technology. In: Prost, R. (Ed.), Contaminated Soils. INRA, Paris, pp. 466-504.

Alloway, B.J., 1995. Heavy Metals in Soils. Blackie Academic Professional, London, p. 368.

Angelone, M., Bini, C., 1992. Trace elements concentrations in soils and plants of Western Europe. In: Adriano, D.C. (Ed.), Biogeochemistry of Trace Metals. Lewis Publishers, Boca Raton, pp. 19-60.

Argese, E., Delaney, E., Agnoli, F., Faraon, F., Sorgano, A., Cacco, G., 2001. Variation of morpho-physiological parameters of barley and oat plants grown on heavy-metal treated microcosms. Bollettino della Società Italiana della Scienza del Suolo 50 (3), 709-722 (in Italian).

Baker, A.J.M., 1981. Accumulators and excluders strategies in the response of plants to heavy metals. Journal of Plant Nutrition 3, 643-654.

Baker, A.M.J., Brooks, R.R., 1989. Terrestrial higher plants which hyperaccumulate metallic elements - a review of their distribution, ecology and phytochemistry. Biorecovery 1, 81-126.

Baker, A., Mc Grath, S., Reeves, R., Smith, J., 2000. Metal hyperaccumulator plants: a review of the ecology and physiology of a biological resource for phytoremediation of metal-polluted soils. In: Terry, N., Banuelos, G. (Eds.), Phytoremediation of Contaminated Soils. Lewis Publisher, London, pp. 85-107.

Bargagli, R., 1993. Plant leaves and lichens as biomonitors of naturals or anthropogenic emissions of mercury. In: Markert, B. (Ed.), Plants as Biomonitors. Weinheim WCH, pp. 468-484.
Bini, C., 2005. Plants growing on abandoned mine soils: a chance in phytoremediation. Proc. III EGU Conf., Wien (CD-rom).

Bini, C., 2010. From soil contamination to land restoration. In: Steinberg, R.V. (Ed.), Contaminated Soils: Environmental Impact, Disposal and Treatment. Nova Science Publisher, New York. ISBN: 978-1-60741-791-0.

Bini, C., Casaril, S., Pavoni, B., 2000a. Fertility gain and heavy metal accumulation in plants and soils. Environmental Toxicology and Chemistry 77, 131-142.

Bini, C., Maleci, L., Gabbrielli, L., Paolillo, A., 2000b. Biological perspectives in soil remediation with reference to chromium. In: Wise, D. (Ed.), Bioremediation of Contaminated Soils. Marcel Dekker Inc., New York, pp. 663-675.

Bini, C., Maleci, L., Romanin, A., 2008. The chromium issues in soils of the leather tannery district in Italy. Journal of Geochemical Exploration 96, 194-202.

Blaylock, M.J., Elles, M.P., Nuttal, C.Y., Zdimal, K.L., Lee, C.R., 2003. Treatment of As contaminated soil and water using Pteris vittata. Proc VI ICOBTE, Uppsala, Sv.

Brooks, R.R., 1998. Phytochemistry of hyperaccumulator. In: Brooks, R. (Ed.), Plants that Hyperaccumulate Heavy Metals: Their Role in Phytoremediation, Microbiology, Archaeology, Mineral Exploration and Phytomining. CAB International, U.K., pp. 15-53.

Brooks, R.R., Robinson, B.H., 1998. The potential use of hyperaccumulators and other plants for phytomining. In: Brooks, R. (Ed.), Plants that Hyperaccumulate Heavy Metals: Their Role in Phytoremediation, Microbiology, Archaeology, Mineral Exploration and Phytomining. CAB International, U.K., pp. 327-356.

Brooks, R.R., Lee, J., Reeves, R.D., Joffrè, T., 1977. Detection of nickeliferous rocks by analysis of herbarium specimens of indicator plants. Journal of Geochemical Exploration 7, 49-77.

Campana, R., Galuppo, A., Mastellone, F., Spagna, V., Toffoletto, F., Zanco, A., 2007. Geologicalenvironmental trekking in Mis and Imperina Valleys (Belluno, NE Italy). Interreg IIIC sud-Resnafront Project, Regione del Veneto, Unione Europea (in Italian).

Corradi, M.G., Levi, M., Musetti, R., Favali, M.A., 1991. The effect of $\mathrm{Cr}^{\mathrm{VI}}$ on different inbred lines of Zea mays. Protoplasma 162, 12-19.

Corradi, M., Bianchi, A., Albasini, A., 1993. Chromium toxicity in Salvia sclarea. Effects of hexavalent chromium on seed germination and seedling development. Environmental and Experimental Botany 33 (3), 405-413.

D.L. - Legislation Act ${ }^{\circ}$ 152/2006. Italian Republic Official Gazette n88, 14/04/2006. (in Italian).

Dubois, J.P., Okopnik, F., Benitez, N., Vedy, J.C., 1998. Origin and spatial variability of cadmium in some soils of the Swiss Jura. Proc. 16th IUSS Congress, Montpellier, Symp., 25, pp. 1-8.

Ernst, W.H.O., 1993. Geobotanical and biogeochemical prospecting for heavy metal deposits in Europe and Africa. In: Markert, B. (Ed.), Plants as Biomonitors. Weinheim WCH, pp. 107-126.

Ernst, W.H.O., 1996. Bioavailability of heavy metals and decontamination of soils by plants. Applied Geochemistry 11, 163-167.

Fontana, S., Wahsha, M., Bini, C., 2010. Preliminary observations on heavy metal contamination in soils and plants of an abandoned mine in Imperina Valley (Italy). Agrochimica 54 (4), 218-231.

Frizzo, P., Ferrara, E., 1994. Mixed sulphides mine district of Agordo-Valsugana (Subalpine Basement, Eastern Alps). Proceedings of the Special Workshop in memory of Prof. Stefano Zucchetti, Torino, pp. 147-154 (in Italian).

Giuliani, C., Pellegrino, F., Tirillini, B., Maleci, L., 2008. Micromorphological and chimica characterization of Stachys recta subsp serpentini (Fiori) Arrigoni in comparison to S. recta subsp. recta (Lamiaceae). Flora 203, 376-385.

Helios-Rybicka, E., 1996. Impact of mining and metallurgical industries on the environment in Poland. Applied Geochemistry 11 (1-2), 3-11.

Hood, T.M., Jones, B.J., 1997. Soil and Plant Analysis in Sustainable Agriculture and Environment. Marcel Dekker Inc., New York, p. 877.

Jenny, H., 1989. The Soil Resource. Springer Verlag, New York, p. 377.

Jones Jr., B.J., 2001. Laboratory Guide for Conducting Soil Tests and Plant Analysis. CRC Press, Boca Raton, p. 363.

Kabata-Pendias, A., 2004. Soil-plant transfer of trace elements. An environmental issue. Geoderma 122, 143-149.

Kabata-Pendias, A., 2011. Trace Elements in Soils and Plants, third ed. CRC Press, Boca Raton, p. 365.

Kabata-Pendias, A., Mukherjee, A.B., 2007. Trace Elements from Soil to Human. Springer Verlag, Berlin, p. 550.

Kabata-Pendias, A., Pendias, H., 2001. Trace Elements in Soils and Plants, second ed. CRC Press, Boca Raton, p. 365.

Keane, B., Collier, M.H., Shann, J.R., Rogstad, S.H., 2001. Metal content of dandelion (Taraxacum officinale) leaves in relation to soil contamination and airborne particulate matter. The Science of the Total Environment 281, 63-78.

Kidd, P., Barcelo, J., Bernal, M.P., Navari-Izzo, F., Poschenrieder, C., Shilev, S., Clemente, R., Monterroso, C., 2009. Trace element behaviour at the root-soil interface: implications in phytoremediation. Environmental and Experimental Botany 67, 243-259.

Królak, E., 2003. Accumulation of $\mathrm{Zn}, \mathrm{Cu}, \mathrm{Pb}$ and $\mathrm{Cd}$ by dandelion (Taraxacum officinale Web.) in environments with various degrees of metallic contamination. Polish Journal of Environmental Studies 12 (6), 713-721.

Lehoczky, E., Szabados, I., Marth, P., 1996. Cadmium content of plants as affected by soil cadmium concentrations. Communications in Soil Science and Plant Analysis 27, 1765-1777.

Lopareva-Pohu, A., Verdin, A., Garçon, G., Sahraoui, A.L., Pourrut, B., Debiane, D., Waterlot, C., Laruelle, F., Bidar, G., Douay, F., Shirali, P., 2011. Influence of fly ash aided phytostabilisation of $\mathrm{Pb}, \mathrm{Cd}$ and $\mathrm{Zn}$ highly contaminated soils on Lolium perenne and Trifolium repens metal transfer and physiological stress. Environmental Pollution 159, 1721-1729.

Malawska, M., Wilkomirski, B., 2001. An analysis of soil and plant (Taraxacum officinale) contamination with heavy metals and polycyclic aromatic hydrocarbons (PAHs) in the area of the railway junction Ilawa Glòwna, Poland. Water, Air, and Soil Pollution $127,339-349$. 
Maleci, L., Gentili, L., Pinetti, A., Bellesia, F., Servettaz, O., 1999. Morphological and phytochemical characters of Thymus striatus Vahl growing in Italy. Plant Biosystems 133 (2), 137-144.

Maleci, L., Bini, C., Paolillo, A., 2001. Chromium (III) uptake by Calendula arvensis L. and related phytotoxicity. Proc. VI ICOBTE, Guelph, On. , p. 384 (abstract).

Malik, R.N., Husain, S.Z., Nazir, I., 2010. Heavy metal contamination and accumulation in soil and wild plant species from industrial area of Islamabad, Pakistan. Journal of Botany 42 (1), 291-301.

Mangabeira, P., Almeida, A.A., Mielke, M., Gomes, F.P., Mushrifah, I., Escaig, F., Laffray, D., Severo, M.I., Oliveira, A.H., Galle, P., 2001. Ultrastructural investigations and electron probe X-ray microanalysis of chromium-treated plants. Proc. VI ICOBTE, Guelph, p. 555 (abstract).

Marchiol, L., Sacco, P., Assolari, S., Zerbi, G., 2004. Reclamation of polluted soils: phytoremediation potential of crop-related Brassica species. Water, Air, and Soil Pollution 158 (1), 345-356.

Margesin, R., Schinner, F., 2005. Manual for Soil Analysis - Monitoring and Assessing Soil Bioremediation, first ed. Springer, Berlin, Germany, p. 359.

Mc Grath, S., 1998. Phytoextraction for soil remediation. In: Brooks, R. (Ed.), Plants that Hyperaccumulate Heavy Metals: Their Role in Phytoremediation, Microbiology, Archaeology, Mineral Exploration and Phytomining. CAB International, U.K., pp. 261-287.

Mikulka, J., Korčáková, M., Burešová, V., Andr, J., 2009. Changes in weed species spectrum of perennial weeds on arable land, meadows and pastures. Plant Protection Science $45,63-66$

Mun, H.W., Hoe, A.L., Koo, L.D., 2008. Assessment of Pb uptake, translocation and immobilization in kenaf (Hibiscus cannabinus L.) for phytoremediation of sand tailings. Journal of Environmental Sciences 20, 1341-1347.

Pandolfini, T., Gremigni, P., Gabbrielli, R., 1997. Biomonitoring of soil health by plants. In: Pankhurst, C., Doube, B.M., Gupta, V.V. (Eds.), Biological Indicators of Soil Health. CAB Int., Wallingford, pp. 325-347.

Preeti, P., Tripathi, A.K., 2011. Effect of heavy metals on morphological and biochemical characteristics of Albizia procera (Roxb.) Benth. seedlings. International Journal of Environmental Science 1, 5.

Rosselli, W., Rossi, M., Sasu, I., 2006. Cd, Cu and Zn contents in the leaves of Taraxacum officinale. Swiss Federal Institute for Forest. Snow and Landscape Research 80 (3), 361-366.

Salt, D.E., Blaylock, M., Kumar, N., Dushenkov, V., Ensley, B.D., Chet, I., Raskin, I., 1995. Phytoremediation: a novel strategy for the removal of toxic metals from the environment using plants. Biotechnology 13, 468-474.

Sarret, G., Vangronsveld, J., Roux, M., Coves, J., Manceau, A., 2001. Bioaccumulation of metal in plants and microorganisms studied by electron microscopy and EXAFS spectroscopy. Proc. VI ICOBTE, Guelph, p. 555 (abstract).
Savinov, A.B., Kurganova, L.N., Shekunov, Y.I., 2007. Lipid peroxidation rates in Taraxacum officinale Wigg. and Vicia cracca L. from biotopes with different levels of soil pollution with heavy metals. Russian Journal of Ecology 38 (3), 174-180.

Simon, L., Martin, H.W., Adriano, D.C., 1996. Chicory (Cichorium intybus L.) and dandelion (Taraxacum officinale Web.) as phytoindicators of cadmium contamination. Water Air, and Soil Pollution 91 (3-4), 351-362.

Turuga, L., Albulescu, M., Popovici, H., Puscas, A., 2008. Taraxacum officinale in phytoremediation of contaminated soils by industrial activities. Annals of West University of Timisoara, Series Chemistry 17 (2), 39-44.

Vandecasteele, B., De Vos, B., Tack, F., 2002. Cadmium and Zinc uptake by volunteer willow species and elder rooting in polluted dredged sediment disposal sites. The Science of the Total Environment 299, 191-205.

Vasquez, M.D., Poschenrieder, C., Barcelo, J., 1991. Ultrastructural effects and localization of low cadmium concentrations in bean roots. The New Phytologist 120, 215-226.

Vergnano Gambi, O., 1992. The distribution and ecology of the vegetation of ultramafic soils in Italy. In: Roberts, B.A., Proctor, J. (Eds.), The Ecology of Areas with Serpentinized Rocks. A World View. Kluwer Academic Press, pp. 217-247.

Wahsha, M., Bini, C., Fontana, S., Wahsha, A., Zilioli, D., 2012. Toxicity assessment of contaminated soils from a mining area in Northeast Italy by using lipid peroxidation assay. Journal of Geochemical Exploration 113, 112-117.

Wenzel, W.W., Sattler, H., Jockwer, F., 1993. Metal hyperaccumulator plants: a survey on species to be potentially used for soil remediation. Agronomy Abstracts, p. 52.

WRB, 2006. World reference base for soil resource, World Soil Resources Reports No. 103, 2nd edition. FAO, Rome, p. 128.

Yang, Y., Nan, Z., Zhao, Z., Wang, Z., Wang, S., Wang, X., Jin, W., Zhao, C., 2011 Bioaccumulation and translocation of cadmium in cole (Brassica campestris L.) and celery (Apium graveolens) grown in the polluted oasis soil, Northwest China. Journal of Environmental Sciences 23 (8), 1368-1374.

Zong, L.G., Sun, J.K., Shen, O.Y., Zhang X.P., 2007. Impacts of cadmium and lead pollution in soil on shoot vegetables growth and toxic-symptoms. Asian Journal of Ecotoxicology 2 (1), 63-68.

Zupan, M., Hudnik, V., Lobnik, F., Kadunc, V., 1995. Accumulation of Pb, Cd, Zn from contaminated soil to various plants and evaluation of soil remediation with indicator plant (Plantago lanceolata). In: Prost, R. (Ed.), Contaminated Soils. INRA, Paris, pp. 325-335.

Zupan, M., Kralj, T., Grcman, H., Hudnik, V., Lobnik, F., 2003. The accumulation of Cd, Zn, $\mathrm{Pb}$ in Taraxacum officinale and Plantago lanceolata from contaminated soils. Proc VI ICOBTE, Uppsala Sv. 